\title{
Extended Release Enteric Coated Capsule Dosage Form
}

National Cancer Institute

\section{Source}

National Cancer Institute. Extended Release Enteric Coated Capsule Dosage Form. NCI

Thesaurus. Code C91140.

An extended release capsule covered with a substance that is designed to delay the release of active and/or inert ingredient(s) until the capsule passes into the intestines. 